\title{
Assessment of Mineral Content Variations for Biofortification of the Bean Seed
}

\author{
Mehmet Zahit Yeken $^{1 *} \quad$ Hacer Akpolat ${ }^{2} \quad$ Tolga Karaköy $^{3} \quad$ Vahdettin Çiftçi1 \\ ${ }^{1}$ Department of Field Crops, Faculty of Agriculture and Natural Sciences, Bolu Abant İzzet Baysal University, Bolu, Turkey \\ 2Department of Food Science and Technology, The Ohio State University, Columbus, USA \\ ${ }^{3}$ Organic Agriculture Program, Vocational School of Sivas, Sivas Cumhuriyet University, Sivas, Turkey
}

\begin{abstract}
Keywords:
Biofortification, micro- and macronutrient, Phaseolus vulgaris $\mathrm{L}$.

\section{*Corresponding author}

yekenmehmetzahit@gmail.com

Abstract. Germplasm collections are very important for breeder to develop new cultivars with high mineral nutrients and yield. Eighty-three Phaseolus landraces were collected from different provinces of Western Anatolia Region of Turkey in 2015-2016. Twenty common bean lines were selected according to morphological characterization results and weighted scaling method in 2016. Phosphorus $(\mathrm{P})$, potassium $(\mathrm{K})$, copper $(\mathrm{Cu})$, zinc $(\mathrm{Zn})$, manganese $(\mathrm{Mn})$, iron $(\mathrm{Fe})$, calcium $(\mathrm{Ca})$, and magnesium $(\mathrm{Mg})$ contents of these twenty common bean lines and two commercial cultivars were tested under field conditions. Randomized block design with three replicates was used for analysis in 2017 growing season on the experimental farm of Bolu Abant Izzet Baysal University. The results showed high level of variation among lines and cultivars in terms of $\mathrm{P}(0.94-1.30 \%), \mathrm{K}(2.38-3.59 \%), \mathrm{Cu}(7.80-14.80 \mathrm{mg}$ $\left.\mathrm{kg}^{-1}\right)$, Zn (19.74-66.68 $\left.\mathrm{mg} \mathrm{kg}^{-1}\right), \mathrm{Mn}\left(7.46-27.25 \mathrm{mg} \mathrm{kg}^{-1}\right)$, Fe (48.98-182.45 mg kg-1), Ca (0.18-0.48 mg $\left.\mathrm{kg}^{-1}\right)$ and $\mathrm{Mg}\left(0.56-0.71 \mathrm{mg} \mathrm{kg}^{-1}\right)$ contents. Positive correlations were found between $\mathrm{K}$ and $\mathrm{Zn}(\mathrm{r}=0.447$; $\mathrm{P}<0.05), \mathrm{P}$ and $\mathrm{Fe}(\mathrm{r}=0.485 ; \mathrm{P}<0.05), \mathrm{Ca}$ and $\mathrm{Mg}(\mathrm{r}=0.693 ; \mathrm{P}<0.01)$. In principal component analysis (PCA), the first 4 principal components accounted for approximately $73 \%$ of the total variability. The lines, Ylv-14, Ylv-32, Blck-7, Blksr-3 and Brs-22 had superior mineral contents for Fe and P, $\mathrm{Cu}$ and $\mathrm{Mn}$, $\mathrm{Ca}$ and $\mathrm{Mg}, \mathrm{Zn}$, and $\mathrm{K}$, respectively. Therefore, these lines represent promising candidates for biofortifying the bean seed and can be registered as cultivars in Turkey. Moreover, these lines will be used further for identifying the QTL regions by developing biparental mapping populations for an effective breeding program in Turkey in near future.
\end{abstract}

\section{Fasulye Tohumunun Biyofortifikasyonu için Mineral içerik Vasyasyonlarının Değerlendirilmesi}

\section{Anahtar kelimeler:} Biyofortifikasyon, mikromakro mineral, Phaseolus vulgaris $\mathrm{L}$.

\begin{abstract}
Özet. Genetik kaynaklar ıslahçıların yüksek verim ve mineral içeriğine sahip yeni çeşitler geliştirebilmesi için çok önemlidir. 2015-2016 yılları arasında Türkiye'nin Batı Anadolu bölgesinin farklı bölgelerinden seksen üç Phaseolus populasyonu toplanmıştır. Morfolojik karakterizasyon sonuçları ve tartılı derecelendirmeye göre yirmi fasulye hattı 2016 yılında seçilmiştir. Yirmi fasulye hattının ve iki ticari çeşidin fosfor, potasyum, bakır, çinko, mangan, demir, kalsiyum ve magnezyum içerikleri tarla koşullarında test edilmiştir. Deneme 2017 yılı yetiştirme periyodunda Bolu Abant İzzet Baysal Üniversitesi, Araştırma ve Uygulama Alanı'nda tesadüf blokları deneme desenine göre üç tekrarlamalı olarak yürütülmüştür. Sonuçlar, fasulye hat ve çeşitleri arasında $\mathrm{P}$ (\%0.94-1.30), K (\%2.38-3.59), Cu (7.80-14.80 mg kg-1), Zn (19.74-66.68 $\left.\mathrm{mg} \mathrm{kg}^{-1}\right), \mathrm{Mn}\left(7.46-27.25 \mathrm{mg} \mathrm{kg}^{-1}\right), \mathrm{Fe}\left(48.98-182.45 \mathrm{mg} \mathrm{kg}^{-1}\right), \mathrm{Ca}\left(0.18-0.48 \mathrm{mg} \mathrm{kg}^{-1}\right)$ ve $\mathrm{Mg}$ (0.56-0.71 $\left.\mathrm{mg} \mathrm{kg}^{-1}\right)$ yüksek oranda varyasyon göstermiştir. $\mathrm{K}$ ve $\mathrm{Zn}(\mathrm{r}=0.447 ; \mathrm{P}<0.05), \mathrm{P}$ ve $\mathrm{Fe}(\mathrm{r}=0.485$; $\mathrm{P}<0.05)$, Ca ve $\mathrm{Mg}(\mathrm{r}=0.693 ; \mathrm{P}<0.01)$ arasında pozitif yönde korelasyon bulunmuştur. Ana bileşen analizine göre toplam çeşitliliğin \% 73'ünden ilk 4 temel komponentin sorumlu olduğu görülmüştür. Ylv14, Ylv-32, Blck-7, Blksr-3 ve Brs-22 hatları sırasıyla Fe ve $\mathrm{P}, \mathrm{Cu}$ ve $\mathrm{Mn}$, Ca ve $\mathrm{Mg}$, Zn, ve K bakımından daha yüksek mineral içeriğine sahip olduğu tespit edilmiştir. Bu sebeplerden dolayı, bu hatlar fasulye tohumlarının biyofortifikasyonu için ümitvar adayları temsil etmekte ve Türkiye'de çeşit olarak tescillenebilir. Ayrıca bu hatlar, yakın gelecekte etkili ıslah programları için biparental haritalama populasyonu geliştirilerek QTL bölgelerinin tanımlanması amacıyla da kullanılabilir.
\end{abstract}




\section{INTRODUCTION}

Common bean (Phaseolus vulgaris L.) is one of the oldest domesticated crops of the New World (Broughton et al., 2003). It is a self-pollinated crop (2n $=2 \mathrm{x}=22$ ) with a small genome size of $587 \mathrm{Mbs}$ (Schmutz et al., 2014). Phaseolus vulgaris L., originated in Latin America, and have two diverse gene pools, Mesoamerican gene pool with small seeds and Andean gene pool with large seeds (Bitocchi et al., 2017). The Mesoamerican gene pool is predominantly found from Colombia up to Mexico, while Andean gene pool extends between South Peru to North Western Argentina (Kwak and Gepts 2009).

Phaseolus vulgaris $\mathrm{L}$. is the most widely cultivated grain legume, and greatly preferred in many parts of Africa, Latin America and Southern Europe (Broughton et al., 2003). Common bean is a vital source of nutrients for nearly 300 million people worldwide (Petry et al., 2015), and known as "poor man's meat" because of its high mineral, protein, and vitamin content (Sperotto and Ricachenevsky 2017), providing health benefits associated with regular consumption (Bitocchi et al., 2017).

Micronutrient malnutrition is a main public health problem in many parts of the world, which is known as "hidden hunger" (Welch and Graham 2004). Micronutrient deficiencies have raised in the last decades in developed and developing countries (Graham et al., 2001). Particularly, the deficiency of Fe and $\mathrm{Zn}$ is a crucial public health problem, and negatively affects the health, lifespan and productivity over 4 billion people worldwide (WHO 2009; Khan et al., 2008).

The production of micronutrient enhanced varieties (biofortified) using agricultural and genetical methods can provide a cost-effective way to overcome micronutrient deficiencies by improving the bioavailability of these important nutrients (Duc et al., 2010). "Biofortification" or "biological fortification" is the process of improving the nutritional status in staple crops by means of modern biotechnology techniques, traditional plant breeding, and agronomic practices (Garg et al., 2018). Collection of local germplasm and characterization of natural biodiversity as a source of novel alleles for biofortifying the crops are of prime importance in 21st century breeding programs. For breeders, the first step of the biofortification in food crops is to understand the current genetic diversity in germplasm collections (Baloch et al., 2014). All mineral elements that are most frequently lacking in human diets are present in genetic variations, and this can be used in breeding studies to increase the levels of minerals and vitamins in crops (White and Broadley 2005). Numerous studies have been conducted to determine the nutritional status of grain legumes. Earlier work by Pinheiro et al. (2010) found a high degree of variability in $\mathrm{P}, \mathrm{Fe}, \mathrm{Zn}$, $\mathrm{Cu}, \mathrm{Mn}, \mathrm{Ca}$ and protein content in a collection of 155 accessions of ancient Portuguese common bean (Phaseolus vulgaris L.) seeds. In another study, Dutta et al. (2016) found a considerable genetic variation in the seed macro and micro-nutrients content with high antioxidant activity among the common bean landraces of Lushai hills of India.

Common bean lines with high levels of nutrients can be combined with superior agronomic characteristics and high yields for better selection, and can be used for biofortification strategies. Studies in Turkish grain legume germplasms (Çiftçi 2009; Kantar 2010; Madakbaş and Ergin 2011; Çiftçi 2012; Elkoca and Çınar 2015; Yeken 2018a; Nadeem et al., 2018) focused mostly on phenological and morphological properties, resistance to important diseases, and quality characteristics. Assessment of mineral content and yield is also important in terms of providing high level of nutrition and high yield at the same time while breeding for new varieties. However, mineral contents of the common bean seeds have not been evaluated before in Western Anatolia Region of Turkey for a better selection of common bean varieties while breeding for fortification and higher yield. Therefore, our objective was to analyses the seed mineral content $(\mathrm{P}, \mathrm{K}, \mathrm{Cu}, \mathrm{Zn}, \mathrm{Mn}, \mathrm{Fe}, \mathrm{Ca}$, and $\mathrm{Mg}$ ) of twenty common bean lines selected for their high yield properties from a germplasm of Western Anatolia Region of Turkey and two commercial cultivars tested under field conditions.

\section{MATERIAL AND METHOD}

\section{Plant Material and Crop Sowing}

Eighty-three Phaseolus landraces were collected from different provinces (Düzce, Yalova, Bilecik, Bursa, Balıkesir, Çanakkale) of Western Anatolia Region of Turkey in 2015-2016. Twenty common bean lines (Phaseolus vulgaris L.) were selected through single plant selection from these local landraces according to morphological characterization results and weighted scaling method in 2016. These promising lines and two commercial cultivars were used as genetic materials in this study. All the passport data of common bean lines were given Table 1 (Figure 1). These common bean lines were tested in randomized block design with three replicates together with two commercial 
cultivars in 2017 at the research and implementation area of Bolu Abant Izzet Baysal University (BAIBU) $\left(40^{\circ} 44^{\prime} 46.71^{\prime \prime} \mathrm{N}, 31^{\circ} 37^{\prime} 45.18^{\prime \prime} \mathrm{E}\right)$, Turkey. All genotypes were sown on May 2017 in the plots consisting two rows of $4 \mathrm{~m}$ long with a row spacing of $45 \mathrm{~cm}$ for bush types, $70 \mathrm{~cm}$ for climber types, and intra row spacing of $10 \mathrm{~cm}$. Common beans were harvested in September 2017. Total precipitation was around 36.9 $\mathrm{kg} \mathrm{m}^{-2}$ during the growing season (from sowing to physiological maturity). The experimental area had a loamy structure revealing a slightly alkaline character. While the soil of the experimental area was poor in terms of organic matter $(1.80-1.86 \%)$, it was rich in terms of available $\mathrm{K}\left(264.3-273.3 \mathrm{mg} \mathrm{kg}^{-1}\right)$ and $\mathrm{P}(20.4$ $\left.31.5 \mathrm{mg} \mathrm{kg}^{-1}\right)$. All mineral elements were within sufficient or excessive limit values except for $\mathrm{Zn}$ content being deficient (Table 2) (Sönmez et al., 2018). After soil analysis, a fertilizer rate of $4 \mathrm{~kg}$ of nitrogen and was given at the time of sowing in the form of ammonium sulphate (21\%). Standard local agricultural practices were applied equally to eliminate the role of environment in all the plots.

\section{Micro- and Macronutrient Analysis}

Micro- and macronutrient concentrations such as $\mathrm{P}, \mathrm{K}, \mathrm{Ca}, \mathrm{Mg}, \mathrm{Fe}, \mathrm{Zn}, \mathrm{Cu}$ and $\mathrm{Mn}$ were investigated in seeds obtained from common bean lines and commercial cultivars. Seed samples were taken from every landrace with 3 replications and seeds were bulked. A closed microwave digestion system (ETHOS EASY, Milestone, Italy) was used to digest the samples $(0.2 \mathrm{~g})$ using $5 \mathrm{~mL}$ of concentrated nitric acid (65\%) and $2 \mathrm{ml}$ of hydrogen peroxide (35\%) (Bremner 1965; Gesto-Seco et al., 2009). After digestion, solutions were transferred to flasks and made up to a final volume of $20.0 \mathrm{~mL}$ with ultra-pure water and then analyzed for mineral nutrients $(\mathrm{K}, \mathrm{Ca}, \mathrm{Mg}, \mathrm{Fe}, \mathrm{Zn}, \mathrm{Cu}$ and $\mathrm{Mn}$ ) with Atomic Absorption Spectrophotometer (Shimadzu AA-7000), and P was measured colorimetrically at $430 \mathrm{~nm}$ in the spectrophotometer (Murphy and Riley 1962; Kacar and İnal 2008; Karaköy and Demirbaş 2017). Mineral contents of each sample were analyzed in triplicates.

\section{Statistical Analysis}

Statistical evaluation of data was performed using analysis of variance (ANOVA), and significant differences between accessions were detected with an $\alpha$ of 0.05 . Correlations between minerals were calculated using the Pearson correlation. Principal component analysis (PCA) based on mineral elements was used to identify the patterns of variance after varimax rotation within the set of twenty common bean lines and two commercial cultivars. XLSTAT 2016 (Addinsoft, New York, USA) was used to perform statistical analyses.

Table 1. Passport data of common bean lines.

Çizelge 1. Fasulye hatlarının pasaport bilgileri.

\begin{tabular}{|c|c|c|c|c|}
\hline No. & Landraces & Geographical province & Latitude (N) & Longitude (E) \\
\hline 1 & Ylv-14 & Yalova-Çiftlikköy-Kabaklı & $40^{\circ} 39^{\prime} 55.92^{\prime \prime}$ & $29^{\circ} 24^{\prime} 43.66^{\prime \prime}$ \\
\hline 2 & Ylv-28 & Yalova-Merkez-Kurtköy & $40^{\circ} 33^{\prime} 12.70^{\prime \prime}$ & $29^{\circ} 12^{\prime} 52.17^{\prime \prime}$ \\
\hline 3 & Ylv-31 & Yalova-Merkez-Hacımehmet & $40^{\circ} 36^{\prime} 56.22^{\prime \prime}$ & $29^{\circ} 14^{\prime} 37.62^{\prime \prime}$ \\
\hline 4 & Ylv-32 & Yalova-Merkez-Sugören & $40^{\circ} 33^{\prime} 38.32^{\prime \prime}$ & 29¹9'34.07" \\
\hline 5 & Blksr-3 & Balıkesir-Manyas-Salur & $40^{\circ} 5^{\prime} 58.61^{\prime \prime}$ & $27^{\circ} 56^{\prime} 16.5^{\prime \prime}$ \\
\hline 6 & Blksr-4 & Balıkesir-Manyas-Akçaova & $40^{\circ} 7^{\prime} 16.8^{\prime \prime}$ & $27^{\circ} 51^{\prime} 15.26^{\prime \prime}$ \\
\hline 7 & Blksr-19 & Balıkesir-Sındırgı-Kürendere & $39^{\circ} 19^{\prime} 6.02^{\prime \prime}$ & $28^{\circ} 34^{\prime} 8.21^{\prime \prime}$ \\
\hline 8 & Brs-3 & Bursa-Yenişehir-Osmaniye & $40^{\circ} 10^{\prime} 18.45^{\prime \prime}$ & $29^{\circ} 37^{\prime} 15.12^{\prime \prime}$ \\
\hline 9 & Brs-4 & Bursa-Inegöl-Cerrah & $40^{\circ} 4^{\prime} 18.83^{\prime \prime}$ & $29^{\circ} 26^{\prime} 7.75^{\prime \prime}$ \\
\hline 10 & Brs-21 & Bursa-Kestel-Kızılören & $40^{\circ} 7^{\prime} 39.19^{\prime \prime}$ & $29^{\circ} 21^{\prime} 9.43^{\prime \prime}$ \\
\hline 11 & Brs-22 & Bursa-Kestel-Aksu & $40^{\circ} 10^{\prime} 2.02^{\prime \prime}$ & $29^{\circ} 18^{\prime} 58.01^{\prime \prime}$ \\
\hline 12 & Brs-23 & Bursa-Kestel-Aksu & $40^{\circ} 10^{\prime} 2.02^{\prime \prime}$ & $29^{\circ} 18^{\prime} 58.01^{\prime \prime}$ \\
\hline 13 & Brs-24 & Bursa-Orhaneli-Küçükorhan & $39^{\circ} 48$ '9.04" & $39^{\circ} 48^{\prime} 9.04^{\prime \prime}$ \\
\hline 14 & Dzc-2 & Düzce-Merkez-Derdin & $40^{\circ} 42^{\prime} 30.06^{\prime \prime}$ & $31^{\circ} 13^{\prime} 20.51^{\prime \prime}$ \\
\hline 15 & Dzc-3 & Düzce-Merkez-Derdin & $40^{\circ} 42^{\prime} 30.06^{\prime \prime}$ & $31^{\circ} 13^{\prime} 20.51^{\prime \prime}$ \\
\hline 16 & Blck-7 & Bilecik-Pazaryeri-Dereköy & $39^{\circ} 59^{\prime} 12.52^{\prime \prime}$ & $29^{\circ} 51^{\prime} 7.17^{\prime \prime}$ \\
\hline 17 & Çnk-2 & Çanakkale-Yenice-Çınarcık & $39^{\circ} 57^{\prime} 6.22^{\prime \prime}$ & $27^{\circ} 10^{\prime} 54.75^{\prime \prime}$ \\
\hline 18 & Çnk-4 & Çanakkale-Biga-Aşağıdemirci & $40^{\circ} 14 ' 38.70^{\prime \prime}$ & $27^{\circ} 22^{\prime} 17.65^{\prime \prime}$ \\
\hline 19 & Çnk-6 & Çanakkale-Biga-Gerlengeç & $40^{\circ} 17^{\prime} 26.36^{\prime \prime}$ & $27^{\circ} 25^{\prime} 14.56^{\prime \prime}$ \\
\hline 20 & Çnk-8 & Çanakkale-Bayramiç-Beşik & $39^{\circ} 44^{\prime} 15.48^{\prime \prime}$ & $26^{\circ} 41^{\prime} 34.82^{\prime \prime}$ \\
\hline 21 & Göynük-98 & \multicolumn{3}{|c|}{ Cultivar/ Transitional Zone Agricultural Research Institute, Eskisehir / Turkey } \\
\hline 22 & Önceler-98 & \multicolumn{3}{|c|}{ Cultivar/ Transitional Zone Agricultural Research Institute, Eskisehir / Turkey } \\
\hline
\end{tabular}




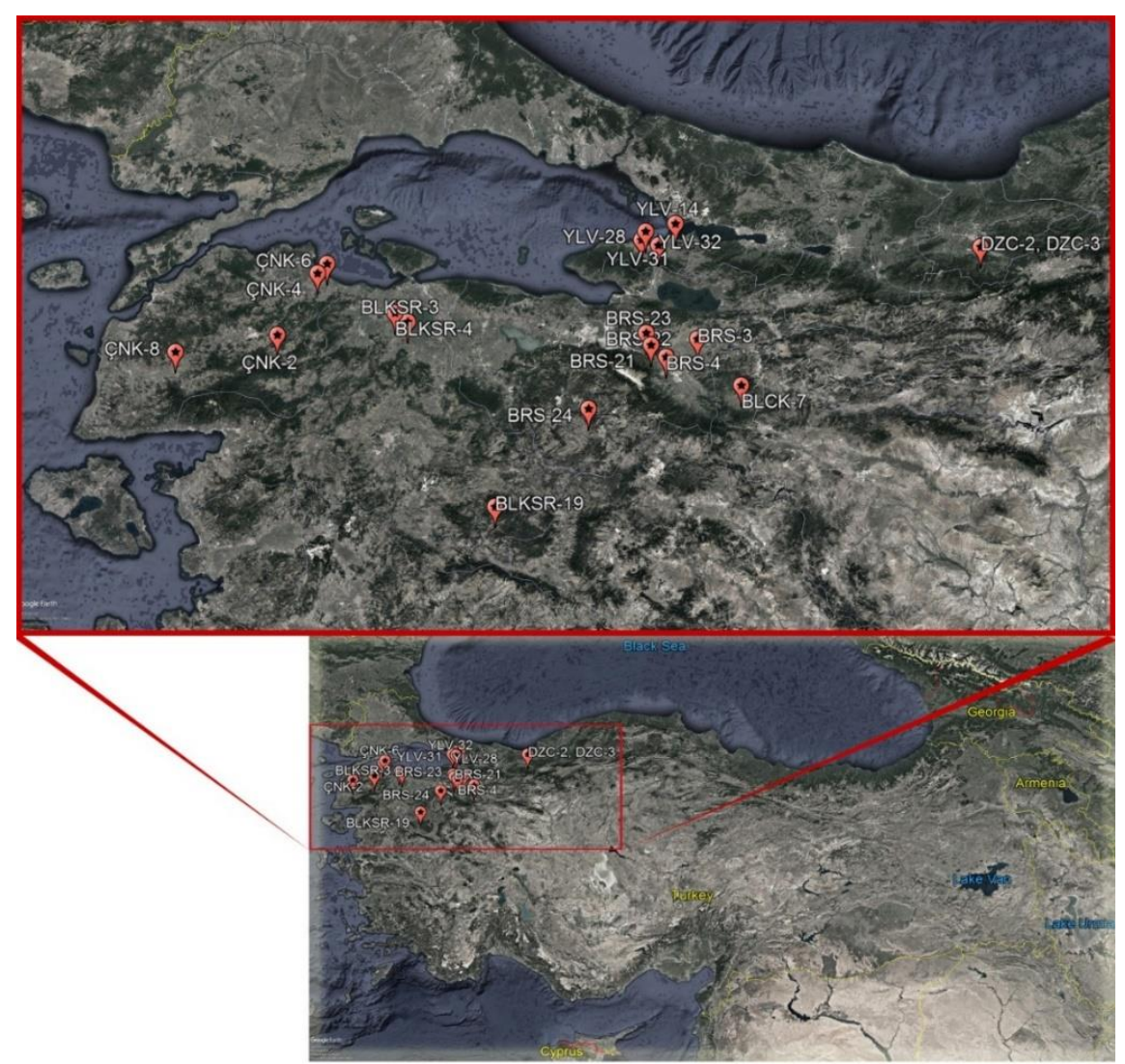

Figure 1. Map of North West of Turkey from which common bean landraces were collected. Provinces where landraces were collected were marked in red.

Şekil 1. Türkiye'nin kuzey batısından toplanılan fasulye populasyonlarının haritası. Fasulye popülasyonlarının toplandığı bölgeler kırmızı ile işaretlenmiştir.

Table 2. Physical characteristics and chemical data $(0-20 \mathrm{~cm}$ and 20-40 depth layer) in experimental area of BAIBU where the $P$. vulgaris lines and cultivars were grown (Sönmez et al., 2018).

Çizelge 2. P. vulgaris hatlarının ve çeşitlerinin yetiştirildiği BAIBU araştırma alanı toprağının $0-20$ ve $20-40 \mathrm{~cm}$ derinlik tabakasındaki fiziksel ve kimyasal özellikleri (Sönmez et al., 2018).

\begin{tabular}{lccc}
\hline Paramaters & Unit & $\mathbf{0 - 2 0} \mathbf{~ c m}$ & $\mathbf{2 0 - 4 0 ~ c m}$ \\
\hline EC & $\mathrm{dS} \mathrm{m}^{-1}$ & 1.516 & 0.635 \\
$\mathrm{pH}$ & & 7.59 & 7.84 \\
Organic Matter & $\%$ & 1.86 & 1.80 \\
Phosphorus (P) & $\mathrm{mg} \mathrm{kg}^{-1}$ & 31.5 & 20.4 \\
Potassium(K) & $\mathrm{mg} \mathrm{kg}^{-1}$ & 273.3 & 264.3 \\
Calcium(Ca) & $\mathrm{mg} \mathrm{kg}^{-1}$ & 4415 & 4446 \\
Magnesium (Mg) & $\mathrm{mg} \mathrm{kg}^{-1}$ & 210.2 & 213.9 \\
Sodium (Na) & $\mathrm{mg} \mathrm{kg}^{-1}$ & 64.30 & 67.42 \\
Iron (Fe), & $\mathrm{mg} \mathrm{kg}^{-1}$ & 16.62 & 17.46 \\
Manganese (Mn) & $\mathrm{mg} \mathrm{kg}^{-1}$ & 4.66 & 4.82 \\
Zinc (Zn) & $\mathrm{mg} \mathrm{kg}^{-1}$ & 2.42 & 2.10 \\
Copper (Cu) & $\mathrm{mg} \mathrm{kg}^{-1}$ & 42.90 & 46.08 \\
Texture & & Loamy & Loamy \\
Lime & $\%$ & 0.63 & 0.74 \\
Sand & $\%$ & 50 & 50 \\
Clay & $\%$ & 22 & 22 \\
Silt & $\%$ & 28 & 28 \\
\hline
\end{tabular}

\section{RESULTS AND DISCUSSION}

Landraces are very important for genetic and breeding studies. It is of great importance to investigate natural biodiversity as a new allelic source to improve yield, adaptability, better cooking characteristics and nutritional value of products in $21^{\text {st }}$ century crop breeding programs. Turkey is not the origin and domestication center of common bean, but common bean landraces distributed in diverse area of Turkey harbor adequate amount of diversity. Characterization of common bean landraces in terms of their nutritional value is crucial for their effective utilization in breeding programs to improve the mineral status of common bean cultivars.

A comprehensive analysis of micronutrient $(\mathrm{Zn}, \mathrm{Fe}$, $\mathrm{Cu}$, and $\mathrm{Mn}$ ) and macronutrient ( $\mathrm{K}, \mathrm{P}, \mathrm{Ca}$, and $\mathrm{Mg}$ ) concentrations was performed for common bean lines and cultivars. Correlations among eight mineral elements ( $\mathrm{P}, \mathrm{K}, \mathrm{Cu}, \mathrm{Zn}, \mathrm{Mn}, \mathrm{Fe}, \mathrm{Ca}$, and $\mathrm{Mg}$ ) in twenty common bean lines and commercial cultivars are given in Table 3. Positive and significant correlations were found between $P$ and $F e(r=0.485 ; P<0.05), K$ and Zn ( $r=0.447$; $\mathrm{P}<0.05)$, Ca and Mg ( $r=0.693 ; \mathrm{P}<0.01)$. On the other hand, $\mathrm{Cu}$ and $\mathrm{Mn}$ were not correlated with 
any of the other minerals. Determination of correlations between minerals of a seed is critical for breeding programs in terms of selection of varieties. Selection of a desired mineral could improve the level of another mineral if there is a positive correlation between the two (Baloch et al., 2014). The positive associations found in this study indicates that selection of a bean with high mineral content may increase the amount of positively correlated mineral indirectly.

In previous studies, correlations were reported in numerous crops, such as Phaseolus vulgaris (Bebee et al., 2000; Pinheiro et al., 2010; Yeken et al., 2018b), lentil (Karaköy et al., 2012), and faba bean (Vicia faba L.) landraces from Turkey (Baloch et al., 2014). The $P$ content was positively correlated with $\mathrm{Fe}$ in this study, and similar findings reported by Bebee et al. (2000) and Pinheiro et al. (2010) in common bean, Baloch et al. (2014) in faba bean and Karaköy et al. (2012) in lentil. Similarly, significant associations of $\mathrm{K}$ and $\mathrm{Zn}$ have been previously reported by Baloch et al. (2014) and Karaköy et al. (2012). In addition, seed Ca and Mg concentrations were significantly correlated to each other, and these results are in agreement with earlier worked by Karaköy et al. (2012). Genetic linkage, pleiotropic, or environmental effects can affect correlations between traits, and the evolution of properties can be influenced by environmental factors in the same or opposite directions (Yücel et al., 2009; Karaköy et al., 2012).

The patterns of variation were evaluated by PCA using twenty common bean lines and commercial cultivars and based on 8 mineral traits. PCA analysis based on the correlation matrix revealed that first five components for all 8 mineral traits explained $87.48 \%$ of the total variance (Table 4). $21.28 \%$ of the variation was explained by the first principal component (PC1). $\mathrm{Mg}$ and $\mathrm{Ca}$ had the highest contribution in PC1. The second principal component (PC2) was highly dependent on $\mathrm{Zn}$ and $\mathrm{K}$, and accounted for $17.57 \%$ of the variability. The third principal component (PC3) accounted for $20.03 \%$ of total variability, and $\mathrm{P}$ and $\mathrm{Fe}$ content had the highest contribution in PC3. The fourth principal component (PC4) explained $13.75 \%$ of the variability with high contribution of $\mathrm{Cu}$ and Fe. The first four principal components were important accounting for approximately $73 \%$ of the total variability.

Table 3. Correlation coefficients among the concentrations of seed mineral elements of common bean lines and commercial cultivars.

Çizelge 3. Fasulye hatlarının ve ticari çeşitlerin tohum mineral elementlerinin konsantrasyonları arasındaki kolerasyon katsayıları.

\begin{tabular}{|c|c|c|c|c|c|c|c|c|}
\hline Variables & $\mathbf{P}$ & $\mathbf{K}$ & $\mathrm{Cu}$ & Zn & Mn & $\mathbf{F e}$ & $\mathrm{Ca}$ & Mg \\
\hline $\mathrm{P}(\%)$ & 1 & -0.236 & -0.021 & 0.089 & -0.204 & $0.485^{*}$ & -0.068 & -0.407 \\
\hline K (\%) & & 1 & 0.137 & $0.447^{*}$ & -0.274 & -0.154 & -0.148 & 0.187 \\
\hline $\mathrm{Cu}\left(\mathrm{mg} \mathrm{kg}^{-1}\right)$ & & & 1 & 0.073 & -0.031 & 0.149 & -0.133 & 0.046 \\
\hline $\mathrm{Zn}\left(\mathrm{mg} \mathrm{kg}^{-1}\right)$ & & & & 1 & 0.087 & -0.177 & -0.042 & 0.112 \\
\hline $\mathrm{Mn}\left(\mathrm{mg} \mathrm{kg}^{-1}\right)$ & & & & & 1 & -0.126 & 0.231 & 0.276 \\
\hline $\mathrm{Fe}\left(\mathrm{mg} \mathrm{kg}^{-1}\right)$ & & & & & & 1 & -0.126 & -0.206 \\
\hline $\mathrm{Ca}\left(\mathrm{mg} \mathrm{kg}^{-1}\right)$ & & & & & & & 1 & $0.693^{* *}$ \\
\hline $\mathrm{Mg}\left(\mathrm{mg} \mathrm{kg}^{-1}\right)$ & & & & & & & & 1 \\
\hline
\end{tabular}

${ }^{*} \mathrm{P}<0.05,{ }^{* *} \mathrm{P}<0.01$

Table 4. Cumulative percentages of variance explained by the first 5 principal components (PCs) of 20 common bean lines and 2 commercial cultivars for contents of some mineral elements.

Çizelge 4. Kümülatif varyans yüzdesi 20 fasulye hattı ve 2 ticari çeşidin bazı mineral elementlerin içerikleri için ilk 5 ana bileşen (PCs) ile açıklanmıştır.

\begin{tabular}{|c|c|c|c|c|c|}
\hline & PC1 & PC2 & PC3 & PC4 & PC5 \\
\hline $\mathrm{Ca}\left(\mathrm{mg} \mathrm{kg}^{-1}\right)$ & 0.922 & -0.079 & 0.054 & -0.166 & 0.129 \\
\hline $\mathrm{Mg}\left(\mathrm{mg} \mathrm{kg}^{-1}\right)$ & 0.889 & 0.121 & -0.286 & 0.125 & 0.066 \\
\hline $\mathrm{Zn}\left(\mathrm{mg} \mathrm{kg}^{-1}\right)$ & 0.008 & 0.958 & 0.056 & 0.002 & 0.099 \\
\hline K (\%) & 0.047 & 0.635 & -0.312 & 0.198 & -0.542 \\
\hline P (\%) & -0.159 & 0.095 & 0.907 & -0.125 & -0.040 \\
\hline $\mathrm{Fe}\left(\mathrm{mg} \mathrm{kg}^{-1}\right)$ & -0.038 & -0.218 & 0.757 & 0.317 & -0.112 \\
\hline $\mathrm{Cu}\left(\mathrm{mg} \mathrm{kg}^{-1}\right)$ & -0.040 & 0.054 & 0.016 & 0.949 & 0.007 \\
\hline $\operatorname{Mn}\left(\mathrm{mg} \mathrm{kg}^{-1}\right)$ & 0.175 & 0.069 & -0.141 & 0.037 & 0.921 \\
\hline Variability (\%) & 21.279 & 17.574 & 20.028 & 13.749 & 14.853 \\
\hline Cumulative \% & 21.279 & 38.853 & 58.881 & 72.630 & 87.483 \\
\hline
\end{tabular}


Table 5 shows the concentrations of $\mathrm{P}, \mathrm{K}, \mathrm{Cu}, \mathrm{Zn}$, $\mathrm{Mn}, \mathrm{Fe}, \mathrm{Ca}$, and $\mathrm{Mg}$ in the seeds of twenty common bean lines and two commercial cultivars including maximum, minimum, mean, coefficient of variation (CV) \% and least significant difference (LSD) values. Statistical analysis of data revealed that bean lines selected from traditional landraces and cultivars were significantly different from each other $(p<0.05)$ for all the studied mineral traits. Moreover, majority of these lines showed significantly higher concentrations of seed mineral content for $\mathrm{Fe}, \mathrm{Mg}, \mathrm{P}$, and Ca relative to the commercial cultivars. The $\mathrm{P}$ content varied from 0.94 (Çnk-4; Brs-23) to $1.30 \%$ (Ylv-32) with a mean value of $1.14 \%$. The $P$ content of commercial cultivars was lower than thirteen lines (Ylv-14,28,31,32; Brs3,4,21; Çnk-6,8; Dzc-2,3; Blksr-3,19). The amount of $\mathrm{K}$ in the studied lines and cultivars varied between $2.38 \%$ for Ylv-28 and $3.59 \%$ for Brs-22 with an average of $2.75 \%$. The $\mathrm{K}$ contents of five lines (Brs-21,22,23; Blksr3; Çnk-2) were significantly higher than cultivars. The overall value of $\mathrm{Cu}$ contents between lines and cultivars was $11.77 \mathrm{mg} \mathrm{kg}^{-1}$, ranging from $7.80 \mathrm{mg}$ $\mathrm{kg}^{-1}$ (Ylv-28) to $14.80 \mathrm{mg} \mathrm{kg}^{-1}$ (Ylv-14). Compared to the cultivars, only Ylv-14 was found to have higher $\mathrm{Cu}$ content than cultivars. The average $\mathrm{Zn}$ content in lines and cultivars was $25.84 \mathrm{mg} \mathrm{kg}^{-1}$ with the lowest $\mathrm{Zn}$ content being in Çnk-4 and Ylv-28 (19.74 $\left.\mathrm{mg} \mathrm{kg}^{-1}\right)$, and the highest value Blksr-3 $\left(66.68 \mathrm{mg} \mathrm{kg}^{-1}\right)$ followed by Dzc-3, Brs-22,24. Mn levels varied between 7.46 and $27.25 \mathrm{mg} \mathrm{kg}^{-1}$ with a mean level of $19.48 \mathrm{mg} \mathrm{kg}^{-1}$. Only, two lines (Ylv-14 and Çnk-6) were higher in Mn content than cultivars. The mean Fe concentration of lines and cultivars was $100.92 \mathrm{mg} \mathrm{kg}^{-1}$ and it varied between $48.98 \mathrm{mg} \mathrm{kg}^{-1}$ (Göynük-98) and $182.45 \mathrm{mg}$ $\mathrm{kg}^{-1}$ (Ylv-32). Fe contents of fifteen lines (Ylv14,28,31,32; Çnk-2,8; Blksr-19; Brs-3,4,21,22,24; Blck-7 and Dzc-2,3) were greater than cultivars. The highest value of Ca content was $0.478 \mathrm{mg} \mathrm{kg}^{-1}$ (Blck-7) while the lowest value was 0.181 (Göynük-98), with an average value of $0.242 \mathrm{mg} \mathrm{kg}^{-1}$. Blck-7, Çnk-6,8, Brs-3, 4, 22, 23, 24, Dzc-2, Blksr-19 and Ylv-28, 31 had significantly higher $\mathrm{Ca}$ concentrations than cultivars. $\mathrm{Mg}$ concentrations varied from 0.558 (Blksr-4) to 0.712 $\mathrm{mg} \mathrm{kg}^{-1}$ (Blck-7), and the mean value was $0.605 \mathrm{mg} \mathrm{kg}^{-}$ 1. The $\mathrm{Mg}$ content of cultivars were higher than Blksr4,19, Çnk-8, Dzc-3 and Ylv-32.

Pinheiro et al. (2010) reported that determination of the mineral content of common beans is important for breeding programs since obtaining elevated levels of minerals has a high value in terms of increasing nutritional quality of the beans. Different ranges for the minerals were reported in the literature (Beebe et al., 2000; Moraghan and Grafton 2001; Pinheiro et al.,
2010; Dutta et al., 2016; Yeken et al., 2018b). The range of $\mathrm{P}$ concentration of common bean lines and cultivars (0.94-1.30\%) were higher than previous studies conducted by Pinheiro et al. (2010), Dutta et al. (2016), and Yeken et al. (2018b). On the other hand, K levels of all lines and cultivars were higher than the levels reported by Pinheiro et al. (2010), but lower than Yeken et al. (2018b). The amount of $\mathrm{Zn}, \mathrm{Fe}, \mathrm{Mn}$ and $\mathrm{Cu}$ in the study were found partially similar to the previous studies (Beebe et al., 2000; Pinheiro et al., 2010; Dutta et al., 2016; Yeken et al., 2018b). For example, one of the possible explanations for high $\mathrm{Fe}$ content of seeds is the high Fe content of the soil (16.62 $\mathrm{mg} \mathrm{kg}^{-1}$ in $0-20 \mathrm{~cm}$ and $17.46 \mathrm{mg} \mathrm{kg}^{-1}$ in $20-40$ $\mathrm{cm}$ ) of the experimental area shown by Sönmez et al., 2018 (Table 2). Additionally, common bean seeds were identified as Mesoamerican germplasm ( $<25 \mathrm{~g})$ and Andean counterpart ( $>25 \mathrm{~g}$ ) using 100 seed weight (Gepts et al., 1986). Seeds used in this study were described as Andean gene pool (data not shown). Compared to Mesoamerican gene pool, Andean and intergene- pool hybrids have higher Fe contents (Blair 2013). The Ca levels were detected lower than Yeken et al. 2018, however they showed partially similar results with Pinheiro et al. (2010). In addition, Mg content was found higher than Pinheiro et al. (2010) and similar to Yeken et al. (2018b). Most of lines had higher level of minerals than the cultivars. Moreover, different mineral levels in the seeds could be explained by genotype, soil composition, and growing season differences (Ceyhan et al., 2008).

\section{CONCLUSIONS}

Mineral content of grain legumes is very important for developing and under-developed countries in terms of providing more nutrition for people, since grain legumes might be a cheaper and more available source of food. The range of $\mathrm{Fe}, \mathrm{Mg}, \mathrm{P}$ and $\mathrm{Ca}$ levels in common bean lines was greater than cultivars. In particular, some common bean lines tested in this study (Ylv-14 for Fe and P, Ylv-32 for Cu and Mn, Blck$7 \mathrm{Ca}$ and $\mathrm{Mg}$, Blksr-3 for Zn, and Brs-22 for K) can play a vital role for human consumption. These common bean lines and information of their mineral content in comparison with cultivars can be used as parents in common bean breeding programs to improve mineral quality of new cultivars. Moreover, these lines can be evaluated for identifying the QTL regions by developing biparental mapping populations for effective breeding program not only in Turkey but also other parts of the world in future studies. 
Table 5. Seed mineral contents of common bean lines in comparison with commercial cultivars and LSD groups. Çizelge 5. Fasulye hatlarının tohum mineral içeriklerinin ticari çeşitlerle karşıllaştırılması ve LSD grupları.

\begin{tabular}{|c|c|c|c|c|c|c|c|c|c|c|c|c|c|c|c|c|}
\hline \multirow[b]{2}{*}{ Blck-7 } & \multicolumn{2}{|c|}{$\begin{array}{l}\mathbf{P} \\
(\%)\end{array}$} & \multicolumn{2}{|c|}{$\begin{array}{l}K \\
(\%)\end{array}$} & \multicolumn{2}{|c|}{$\begin{array}{c}\mathrm{Cu} \\
\left(\mathrm{mg} \mathrm{kg}^{-1}\right)\end{array}$} & \multicolumn{2}{|c|}{$\begin{array}{c}\mathrm{Zn} \\
\left(\mathrm{mg} \mathrm{kg}^{-1}\right) \\
\end{array}$} & \multicolumn{2}{|c|}{$\begin{array}{c}\text { Mn } \\
\left(\mathrm{mg} \mathrm{kg}^{-1}\right)\end{array}$} & \multicolumn{2}{|c|}{$\begin{array}{c}\mathrm{Fe} \\
\left(\mathrm{mg} \mathrm{kg}^{-1}\right) \\
\end{array}$} & \multicolumn{2}{|c|}{$\begin{array}{c}\mathrm{Ca} \\
\left(\mathrm{mg} \mathrm{kg}^{-1}\right)\end{array}$} & \multicolumn{2}{|c|}{$\begin{array}{c}\text { Mg } \\
\left(\mathbf{m g ~ k g}^{-1}\right)\end{array}$} \\
\hline & 1.12 & h & 2.42 & o & 12.42 & e & 22.93 & g & 23.85 & $\mathrm{~cd}$ & 100.13 & g & 0.478 & a & 0.712 & a \\
\hline Blksr-3 & 1.19 & ef & 3.28 & $b$ & 11.67 & $f$ & 66.68 & a & 22.89 & de & 80.36 & jk & 0.226 & 1 & 0.620 & $d$ \\
\hline Blksr-4 & 1.07 & ij & 2.44 & no & 12.27 & e & 23.87 & $f$ & 21.20 & gh & 76.86 & I & 0.210 & I & 0.558 & $\mathrm{n}$ \\
\hline Blksr-19 & 1.19 & ef & 2.77 & g & 11.28 & gh & 21.66 & ij & 19.24 & I & 167.86 & $b$ & 0.240 & g & 0.562 & $\begin{array}{l}\mathrm{m} \\
\mathrm{n}\end{array}$ \\
\hline Brs-3 & 1.18 & $\mathrm{fg}$ & 2.46 & $\mathrm{mn}$ & 10.79 & ij & 24.84 & e & 21.66 & $\mathrm{fg}$ & 85.10 & I & 0.257 & $d$ & 0.588 & hı \\
\hline Brs-4 & 1.21 & $\mathrm{~cd}$ & 2.61 & $\mathrm{kl}$ & 10.53 & jk & 22.79 & gh & 22.66 & ef & 97.87 & g & 0.254 & de & 0.598 & g \\
\hline Brs-21 & 1.17 & g & 3.04 & c & 11.54 & $\mathrm{fg}$ & 21.12 & j & 7.53 & j & 119.15 & c & 0.190 & o & 0.587 & hı \\
\hline Brs-22 & 1.12 & $\mathrm{~h}$ & 3.59 & a & 13.26 & $d$ & 27.74 & $b$ & 7.51 & j & 100.00 & g & 0.252 & ef & 0.629 & c \\
\hline Brs-23 & 0.94 & I & 3.05 & c & 12.51 & e & 25.96 & $d$ & 21.84 & efg & 54.21 & $\mathrm{~m}$ & 0.277 & c & 0.670 & $b$ \\
\hline Brs-24 & 1.06 & j & 2.60 & I & 10.22 & k & 27.62 & $b c$ & 24.31 & $b c$ & 105.98 & $f$ & 0.278 & c & 0.613 & $f$ \\
\hline Çnk-2 & 1.00 & k & 2.99 & $d$ & 11.06 & hı & 22.16 & ghı & 21.09 & gh & 110.90 & e & 0.218 & j & 0.630 & c \\
\hline Çnk-4 & 0.94 & I & 2.63 & jk & 11.10 & hı & 20.24 & k & 20.42 & $\mathrm{~h}$ & 78.67 & $\mathrm{kl}$ & 0.215 & k & 0.613 & ef \\
\hline Çnk-6 & 1.21 & $\mathrm{~cd}$ & 2.69 & $\mathrm{~h}$ & 11.54 & $\mathrm{fg}$ & 22.74 & gh & 25.08 & $b$ & 78.06 & $\mathrm{kl}$ & 0.281 & $b$ & 0.592 & $\mathrm{~h}$ \\
\hline Çnk-8 & 1.25 & $b$ & 2.67 & hı & 11.23 & gh & 23.79 & f & 8.19 & j & 115.11 & $d$ & 0.241 & g & 0.571 & $\mathrm{kl}$ \\
\hline Dzc-2 & 1.20 & de & 2.83 & ef & 13.46 & $c d$ & 26.83 & c & 22.58 & ef & 82.98 & ij & 0.250 & $f$ & 0.619 & de \\
\hline Dzc-3 & 1.18 & $\mathrm{fg}$ & 2.48 & $\mathrm{~m}$ & 13.72 & bc & 28.17 & b & 7.46 & j & 90.65 & $\mathrm{~h}$ & 0.194 & $n$ & 0.575 & k \\
\hline Ylv-14 & 1.17 & $\mathrm{~g}$ & 2.64 & j & 14.80 & $a$ & 25.10 & e & 27.25 & a & 165.71 & $b$ & 0.186 & $p$ & 0.628 & c \\
\hline Ylv-28 & 1.22 & c & 2.38 & $p$ & 7.80 & $\mathrm{~m}$ & 19.74 & k & 18.78 & 1 & 97.83 & g & 0.236 & $\mathrm{~h}$ & 0.625 & $\mathrm{~cd}$ \\
\hline Ylv-31 & 1.19 & ef & 2.81 & $f$ & 8.64 & I & 23.84 & $f$ & 20.54 & $\mathrm{~h}$ & 98.54 & g & 0.237 & $\mathrm{~h}$ & 0.583 & ij \\
\hline Ylv-32 & 1.30 & $a$ & 2.47 & $\mathrm{~m}$ & 14.05 & $b$ & 21.98 & hı & 18.78 & I & 182.45 & a & 0.204 & $\mathrm{~m}$ & 0.566 & Im \\
\hline Göynük-98 & 1.08 & 1 & 2.75 & g & 14.05 & $b$ & 21.80 & ij & 24.59 & bc & 48.98 & $\mathrm{n}$ & 0.181 & $q$ & 0.581 & j \\
\hline Önceler-98 & 1.13 & $\mathrm{~h}$ & 2.85 & e & 10.93 & hı & 26.85 & c & 21.11 & gh & 82.75 & ij & 0.228 & I & 0.587 & hı \\
\hline Min & 0.94 & & 2.38 & & 7.80 & & 19.74 & & 7.46 & & 48.98 & & 0.181 & & 0.558 & \\
\hline Max & 1.30 & & 3.59 & & 14.80 & & 66.68 & & 27.25 & & 182.45 & & 0.478 & & 0.712 & \\
\hline Mean & 1.14 & & 2.75 & & 11.77 & & 25.84 & & 19.48 & & 100.92 & & 0.242 & & 0.605 & \\
\hline CV\% & 1.77 & & 0.55 & & 2.01 & & 1.96 & & 3.33 & & 1.77 & & 0.734 & & 0.57 & \\
\hline LSD (0.05) & 2.94 & & 0.025 & & 0.39 & & 0.84 & & 1.07 & & 2.94 & & 0.003 & & 0.0057 & \\
\hline
\end{tabular}




\section{ACKNOWLEDGEMENTS}

The seeds used in this study was provided by The Scientific and Technological Research Council of Turkey (TUBITAK Project number: 115R042). We would like to thank to the Transitional Zone Agricultural Research Institute. The authors would like to thank Dr. Faheem Shehzad BALOCH and MSc. Yeter ÇiLESIZ.

\section{REFERENCES}

Addinsoft 2016. XLSTAT 2016: Data Analysis and Statistics Software for Microsoft Excel. New York, USA.

Baloch FS., Karaköy T., Demirbaş A., Toklu F., Özkan H and Hatipoğlu R., 2014. Variation of some seed mineral contents in open pollinated faba bean (Vicia faba L.) landraces from Turkey. Turkish Journal of Agriculture and Forestry, 38: 591-602.

Beebe S., Gonzalez A and Rengifo J., 2000. Research on trace minerals in the common bean. Food and Nutrition Bulletin, 21: 387-391.

Bitocchi E., Rau D., Bellucci E., Rodriguez M., Murgia ML., Gioia T., Santo D., Nanni L., Attene G and Papa R., 2017. Beans (Phaseolus ssp.) as a model for understanding crop evolution. Frontiers in Plant Science, 8: 722.

Blair MW., Monserrate F., Beebe SE., Restrepo J and Ortubé J., 2010. Registration of high mineral common bean germplasm lines NUA35 and NUA56 from the red mottled seed class. Journal of Plant Growth Regulation, 4: $1-5$.

Blair MW., 2013. Mineral biofortification strategies for food staples: the example of common bean. Journal of Agricultural and Food Chemistry, 61: 8287-8294.

Bremner JM., 1965. Method of Soil Analysis. Part 2. Chemical and Microbiological Methods, American Society of Agronomy Inc. USA.

Broughton WJ., Hernandez G., Blair M., Beebe S., Gepts P and Vanderleyden J., 2003. Bean (Phaseolus spp.)-model food legumes. Plant Soil, 252: 55-128.

Ceyhan E., Harmankaya M and Avcı MA., 2008. Effects of sowing dates and cultivars on protein and mineral contents of bean (Phaseolus vulgaris L.). Asian Journal of Chemistry, 20(7): 5601-5613.

Çiftçi V., Şensoy S and Türkmen Ö., 2009. Van-Gevaş'ta Yaygın Olarak Yetiştirilen Yalancı Dermason Fasulye Populasyonunun Seleksiyon Yöntemiyle Islahı, Project report (TOVAG- 1060346).

Çiftçi V., Şensoy S and Kulaz H., 2012. Doğu Anadolu'nun Güneyinde Yetiştirilen Fasulye Gen Kaynaklarının Toplanması Ve Değerlendirilmesi, Tübitak Project Report (1090163).

Duc G., Bao S., Baum M., Redden B., Sadiki M., Suso MJ., Vishniakova M and Zong X., 2010. Diversity maintenance and use of Vicia faba L. genetic resources. Field Crops Research, 115: 270-278.

Dutta SK., Chatterjee D., Sarkar D., Singh SB., Boopathi T., Kuotsu R., Vikramjeet K., Akoijam RS., Saha S., Vanlalhmangaiha., Malsawmzuali., Chowdhury $S$ and Lungmuana., 2016. Common bean (Phaseolus vulgaris L., Fabaceae), landraces of Lushai hills in India: nutrients and antioxidants source for the farmers. Indian Journal of Traditional Knowledge, 15(2): 313-320.

Elkoca E and Çınar T., 2015. The adaptation, agronomical and quality characteristcs of some dry bean (Phaseolus vulgaris L.) cultivars and lines under Erzurum ecological conditions. Anadolu Tarım Bilimleri Dergisi, 30(2): 141 153.

Garg M., Sharma N., Sharma S., Kapoor P., Kumar A., Chunduri V and Arora P., 2018. Biofortified crops generated by breeding agronomy and transgenic approaches are improving lives of millions of people around the world. Frontiers in Nutrition, 5: 12.

Graham RD., Welch RM and Bouis HE., 2001. Addressing micronutrient malnutrition through enhancing the nutritional quality of staple foods: principles, perspectives and knowledge gaps. Advances in Agronomy, 70: 77-142.

Gelin JR., Forster S., Grafton SK., McClean PE and RojasCifuentes GA., 2007. Analysis of seed zinc and other minerals in a recombinant inbred population of navy bean (Phaseolus vulgaris L.). Crop Science, 47: 1361-13.

Gepts PTC., Osborn K., Rashka K and Bliss FA., 1986. Phaseolin protein variability in wild forms and landraces of the common bean (Phaseolus vulgaris): evidence for multiple centers of domestication. Economic Botany, 40: 451-468.

Gesto-Seco EM., Moreda-Pineiro A., Bermejo-Barrera A and Barrera-Bermejo P., 2009. Multi-element determination in raft mussels by fast microwave-assisted acid leaching and inductively coupled plasma-optical emission spectrometry. Talanta, 72: 1178-1185.

Islam FMA., Basford KE., Jara C., Redden RJ and Beebe SE., 2002. Seed compositional and disease resistance differences among gene pools in cultivated common bean. Genetic Resources and Crop Evolution, 49: 285293.

Kacar B and İnal A., 2008. Bitki Analizleri. Nobel Yayın Dağıtım, Ankara.

Kantar F., Elkoca E., Eken C and Dönmez F., 2010. Kuzey Doğu Anadolu Bölgesi ve Çoruh Vadisi'nde Yetiştirilen Kuru Fasulye Gen Kaynaklarının Toplanması ve Değerlendirilmesi. Tubitak Project Report (1070400).

Karaköy T., Erdem H., Baloch FS., Toklu F., Eker S., Kilian B and Özkan H., 2012. Diversity of macro-and micronutrients 
in the seeds of lentil landraces. The Scientific World Journal, 2012: 1-9.

Karaköy T and Demirtaş A., 2017. Sivas ekolojik koşullarında yetiştirilen Türkiye orijinli yerel bezelye (Pisum sativum L.) genotiplerinin bazı besin elementi içerikleri bakımından değerlendirilmesi. Adnan Menderes Üniversitesi Ziraat Fakültesi Dergisi, 14(2): 7-11.

Khan MA., Fuller MP and Baloch FS., 2008. Effect of soil applied zinc sulphate on wheat (Triticum aestivum L.) grown on a calcareous soil in Pakistan. Cereal Research Communications, 36: 571-582.

Kwak M and Gepts P., 2009. Structure of genetic diversity in the two major gene pools of common bean (Phaseolus vulgaris L., Fabaceae). Theoretical and Applied Genetics, 118: 979-992.

Madakbaş SY and Ergin M., 2011. Morphological and phenological characterization of Turkish bean (Phaseolus vulgaris L.) genotypes and their present variation states. African Journal of Agricultural Research, 6(28): 61556166.

Moraghan JT and Grafton K., 2001. Genetic diversity and mineral composition of common bean seed. Journal of the Science of Food and Agriculture, 81: 404-408.

Murphy J and Riley JP., 1962. A modified single solution for the determination of phosphate in natural waters. Analytica Chimica Acta, 27: 31-36.

Nadeem MA., Habyarimana E., Çiftçi V., Nawaz MA., Karaköy T., Comertpay G., Shahid MQ., Hatipoğlu R., Yeken MZ., Ali F., Ercişli S., Chung G and Baloch FS., 2018. Characterization of genetic diversity in Turkish common bean gene pool using phenotypic and whole-genome DArTseq-generated silicoDArT marker information. PloS one, 13(10): e0205363.

Petry N., Boy E., Wirth JP and Hurrell RF., 2015. Review: the potential of the common bean (Phaseolus vulgaris) as a vehicle for iron biofortification. Nutrients, 7(2): 11441173.

Pinheiro C., Baeta JP., Pereira AM., Domingues $\mathrm{H}$ and Ricardo CP., 2010. Diversity of seed mineral composition of Phaseolus vulgaris L. germplasm. Journal of Food Composition and Analysis, 23(4): 319-325.
Schmutz J., McClean PE., Mamidi S., Wu GA., Cannon SB., Grimwood J., Jenkins J., Shu S., Song Q., Chavarro C., Torres-Torres M., Geffroy V., Moghaddam S., Gao D., Abernathy B., Barry K., Blair M., Brick MA., Chovatia M., Gepts P., Goodstein DM., Gonzales M., Hellsten U., Hyten DL., Jia G., Kelly JD., Kudrna D., Lee R., Richard MM., Miklas PN., Osorno JM., Rodrigues J., Thareau V., Urrea CA., Wang M., Yu Y., Zhang M., Wing RA., Cregan PB., Rokhsar DS and Jackson SA., 2014. A reference genome for common bean and genome-wide analysis of dual domestications. Nature Genetics, 46: 707-13.

Sönmez F., Gülser F., Karaca S and Gökkaya T., 2018. Determination of some physical and chemical properties of research area soils of Bolu Abant İzzet Baysal University. International Journal of Agricultural and Wildlife Sciences, 4(1): 68-78.

Sperotto RA and Ricachenevsky FK., 2017. Common bean Fe biofortification using model species' lessons. Frontiers in Plant Science, 8: 2187.

Welch RM and Graham RD., 2004. Breeding for micronutrients in staple food crops from a human nutrition perspective. Journal of Experimental Botany, 55: 353-364.

White PJ and Broadley MR., 2005. Biofortifying crops with essential mineral elements. Trends in Plant Science, 10: 586-593.

WHO 2009. Global health risks, mortality and burden of disease attributable to selected major risks. Geneva, Switzerland, WHO.

Yeken MZ., Kantar F., Çancı H., Özer G and Çiftçi V., 2018a. Breeding of dry bean cultivars using Phaseolus vulgaris landraces in Turkey. International Journal of Agricultural and Wildlife Sciences, 4(1): 45-54.

Yeken MZ., Baloch FS., Nadeem MA., Çiftçi V and Karaköy T., 2018b. Variation of some seed mineral contents in 236 bean (Phaseolus vulgaris L.) landraces in Turkey. International Agriculture Congress, 3-6 May, Komrat, Moldova.

Yücel C., Baloch FS and Ozkan H., 2009. Genetic analysis of some physical properties of bread wheat grain (Triticum aestivum L. em Thell). Turkish Journal of Agriculture and Forestry, 33: 525-535. 